\title{
Rootstock Affects Scion Nutrition and Fruit Quality during Establishment and Early Production of 'Honeycrisp' Apple
}

\author{
Nadia A. Valverdi and Lee Kalcsits \\ Department of Horticulture, Tree Fruit Research and Extension Center, \\ Washington State University, 1100 North Western Avenue, Wenatchee, WA \\ 98801
}

Additional index words. Malus $\times$ domestica, mineral nutrients, drought, nutrient partitioning, bitter pit

\begin{abstract}
Honeycrisp' apple is susceptible to bitter pit, which is associated with fruit mineral nutrient composition. Rootstock genotypes can affect nutrient acquisition, distribution, and fruit yields, which all affect fruit nutrient composition and bitter pit susceptibility. However, the changes of these traits among different rootstock genotypes in response to abiotic stress under semiarid conditions are relatively unknown. The objective of this study was to evaluate the influence of different rootstocks and irrigation on nutrient uptake and partitioning with 'Honeycrisp' apple grown in an irrigated, semiarid environment. 'Honeycrisp' apple trees were grafted on four different rootstocks, Geneva 41 ('G.41'), Geneva 890 ('G.890'), M.9-T337 ('M.9'), and Budagovsky 9 ('B.9'), and these were planted at high density (3000 trees/ha). Irrigation was applied as either a water-limited treatment where volumetric soil water content was maintained near $50 \%$ field capacity (FC) and a well-watered control where soil water content was maintained near $100 \%$ FC. 'G.890', the most vigorous rootstock, had lower nitrogen and higher potassium content in leaves, while 'B.9', the least vigorous rootstock, had lower potassium and higher nitrogen content. Rootstock genotype did not affect calcium uptake. Interestingly, water-limited conditions increased the nutrient content in root and stems but not in leaves. Water-limited trees partitioned more nitrogen and calcium to roots, while well-watered trees in the control partitioned more nutrients to the stems. Fruit size was the largest for 'G.890' and smallest for 'B.9'. Both 'G.41' and 'G.890' had higher bitter pit incidence, which was associated with higher potassium content in leaves and fruit. These results suggest that rootstock-induced vigor and irrigation can both contribute to nutrient imbalances in leaves and fruit that could affect the development of physiological disorders in 'Honeycrisp' apple.
\end{abstract}

'Honeycrisp' (Malus $\times$ domestica Borkh.) is a popular high-value apple cultivar bred by the University of Minnesota and released in 1990. 'Honeycrisp' was first planted in Washington State and has expanded from

\footnotetext{
Received for publication 6 Oct. 2020. Accepted for publication 4 Dec. 2020.

Published online 13 January 2021.

This research was funded by the U.S. Department of Agriculture (USDA), National Institute of Food and Agriculture-Specialty Crop Research Initiative project "AppleRoot2Fruit: Accelerating the development, evaluation, and adoption of new apple rootstocks" (2016-51181-25406). L.K. was supported by the USDA National Institute of Food and Agriculture, Multi-State project 227451 and Hatch project 1014919

We would like to acknowledge Katie Mullin, Michelle Reid, and Hector Camargo-Alvarez for technical assistance and Chris Sater for assistance with manuscript revision.

L.K. is the corresponding author. E-mail: lee. kalcsits@wsu.edu.

This is an open access article distributed under the CC BY-NC-ND license (https://creativecommons. org/licenses/by-nc-nd/4.0/).
}

120 ha in 2000 to 9150 ha in 2017 (Gallardo et al., 2015; Serban, 2018). 'Honeycrisp' is challenging to grow because of its high susceptibility to physiological disorders such as bitter pit, which normally causes losses of $\approx 20 \%$, but which can be up to $75 \%$ in extreme cases (Cheng and Sazo, 2018; Kalcsits et al., 2019). Despite these challenges, Washington State growers continue to produce 'Honeycrisp' due to its high economic value, which is almost three times higher than most other popular apple cultivars (Cheng and Sazo, 2018). However, losses to physiological disorders continue to limit the longterm sustainability of 'Honeycrisp'. Bitter pit is associated with localized calcium deficiencies in fruit (Casierra-Posada et al., 2003; de Freitas et al., 2015; Rosenberger et al., 2004). Because calcium is taken up through xylem flow and is phloem immobile, changes to the transpiration balance between leaves and fruit may affect the allocation of calcium to developing fruit (Bisbis et al., 2019; de Freitas et al., 2015; Kalcsits et al., 2020). Moreover, rootstocks have also been reported to strongly influence nutrient acqui- sition from the soil and distribution in the scion (Fazio et al., 2013, 2019; Ferguson and Watkins, 1989; Kucukyumuk and Erdal, 2011; Valverdi et al., 2019). Fazio et al. (2013) reported a quantitative trait locus for potassium and magnesium that were found to be colocated in the same chromosome in apples, and in the same region as one of the dwarfing loci; it can be used to improve nutrient acquisition for new apple rootstocks (Fazio et al., 2019).

In horticultural crops, heat and drought can affect plant growth, yield, and quality (Atkinson et al., 1998; Valverdi et al., 2019). Revisions to climate change forecasts indicate greater impacts than initially anticipated (Zandalinas et al., 2018). Extreme weather events associated with these changes include extended heat, drought, and frost, which can be challenging for horticultural crop production (Bisbis et al., 2019). In many horticultural crops, the impact of these events on productivity has been understudied. For perennial tree crops such as apple, early orchard establishment is an especially important period that can have long-term implications on orchard productivity and economic viability. When conducting field-based experiments, one should take the interaction of several types of abiotic stresses such as heat, drought, and light intensity into consideration because these stresses often occur simultaneously in natural conditions (Grant, 2012). The development of resilient cultivars and rootstocks that are tolerant to abiotic stress may be a useful approach to mitigate the effects of climate change.

Physiological disorders in the fruit have been reported to be associated with nutrient imbalances more than the content of an individual mineral nutrient (Casierra-Posada and Lizarazo, 2004; de Freitas et al., 2015). To better understand the influence of rootstocks on these fruit physiological disorders, several studies with different rootstock genotypes have been conducted at a local and national level (Autio et al., 2020; Lordan et al., 2017; Neilsen and Hampson, 2014; Reig et al., 2018; Tworkoski and Fazio, 2011; Valverdi et al., 2019). GENEVA ${ }^{\circledR}$ series rootstocks bred at the United States Department of Agriculture, Agricultural Research Service (USDA-ARS) Apple Rootstock Breeding and Evaluation Program have been released with an emphasis on productivity, yield efficiency, and tolerance to extreme temperatures, among others (Auvil, 2016). GENEVA ${ }^{\circledR}$ rootstocks have demonstrated similar productivity and quality compared with the current commercial standards, 'M.9' and 'M.26', while introducing increased fire blight and replant disease tolerance as reported in many rootstock trials in North America and other locations worldwide (Autio, 2001; Fallahi et al., 2002; Fazio et al., 2014; Lordan et al., 2017, 2019; Marini and Fazio, 2018; Marini et al., 2012, 2014; Neilsen and Hampson, 2014; Tworkoski and Fazio, 2016). However, the tolerance of these rootstocks to changes in irrigation volume, or how they affect overall nutrient partitioning - and how these responses 
relate to productivity, fruit quality, and disorder incidence - have not been addressed in a semiarid environment.

Here, the objective was to determine how different rootstocks and water limitations affect nutrient uptake and partitioning for 'Honeycrisp' apple grown in field conditions in an irrigated, semiarid climate. Additionally, the differences among rootstock genotypes in early production of fruit quality and fruit nutrient concentration were assessed. We hypothesized that rootstock genotypes would affect the nutrient uptake capacity and this response would also be affected by water limitations. These results will contribute to better recommendations for rootstocks suitable for 'Honeycrisp' apple and provide information on the use of water as a tool to control vigor and optimize nutrient balance in apple.

\section{Materials and Methods}

Plant material. 'Honeycrisp' apple trees were grafted on four different rootstocks: Geneva 41 ('G.41'), Geneva 890 ('G.890'), M.9-T337 ('M.9'), and Budagovsky 9 ('B.9'), and these were planted in 2016 at the Washington State University Tree Fruit Research and Extension Center (WSU-TFREC) Sunrise Orchard in Rock Island, WA (lat. $47^{\circ} 18^{\prime} 35.6^{\prime \prime} \mathrm{N}$, long. $120^{\circ} 03^{\prime} 59.5^{\prime \prime} \mathrm{W}$ ) in a shallow sandy loam soil. Trees were trained to a spindle system at a spacing of $0.9 \mathrm{~m}$ between trees and $3.6 \mathrm{~m}$ between rows. During 2017 and 2018, trees were drip irrigated using emitters spaced $0.3 \mathrm{~m}$ apart that applied $3.78 \mathrm{~L} \cdot \mathrm{h}^{-1}$ water for $2 \mathrm{~h}$ (four sets of $30 \mathrm{~min}$ each) daily. Based on a soil nutrient analysis (Table 1), trees were fertilized in April with $5 \mathrm{~kg} \mathrm{~N}, 18 \mathrm{~kg} \mathrm{P}, 52 \mathrm{~kg} \mathrm{~K}, 83 \mathrm{~kg} \mathrm{~S}, 46 \mathrm{~kg} \mathrm{Ca}$, and $15 \mathrm{~kg} \mathrm{Mg}$ per ha. for both years. Foliar applications of boron and zinc were also applied in April both years to prevent micronutrient deficiencies. Air temperature, relative humidity, precipitation, and wind speed were obtained through the WSU AgWeatherNet weather station located at the WSU-Sunrise Orchard (Table 2). The experiment was arranged in a completely randomized design with two factors: rootstock ('G.41', 'G.890', 'B.9', and 'M.9') and irrigation treatment (control and drought). Each treatment (8) had three replications of five trees, where the outer trees were border trees and the inner trees were used for measurements.

Irrigation treatments. Irrigation treatments were initiated $30 \mathrm{~d}$ after full bloom and maintained throughout the growing sea- son for $\approx 90 \mathrm{~d}$. Irrigation treatments consisted of a water-limited (drought) treatment where soil water content was maintained near $50 \%$ field capacity (FC), and a well-watered control with soil water content maintained near $100 \%$ FC. Before the onset of the experiment, field capacity for this soil was estimated to be $\approx 33 \% \mathrm{v} / \mathrm{v}$. In the orchard, soil volumetric water content and soil temperature were measured with an $\mathrm{ECH}_{2} \mathrm{O} 5 \mathrm{TM}$ soil moisture and temperature probe (Decagon Devices, Pullman, WA) placed $20 \mathrm{~cm}$ deep in the herbicide strip directly between trees, and two irrigation drip emitters in each row (4) for 'M.9' and 'G.890' trees (12 sensors in total). Each soil probe was interfaced with an EM50G cellular data logger (Decagon Devices, Pullman, WA), and data were logged every 30 min during both years from April to September. All blossoms were removed from the trees in 2017 and 2018.

In 2018 and 2019, a separate set of trees (three replications of three trees) bearing fruit from the same orchard were used to analyze rootstock effects on fruit quality and fruit nutrient content. Within $30 \mathrm{~d}$ of fruit set, trees were thinned to a crop load of $\approx 4 \mathrm{fruit} / \mathrm{cm}^{2}$ of trunk cross-sectional area. Trees were fully irrigated to maintain soil moisture content between $85 \%$ to $100 \%$ FC. Bearing trees were harvested on 31 Aug. in 2018 and 3 Sept. in 2019, and total fruit per tree were counted. A sample of eight fruit from each replicate was used for fruit-quality assessments. Fruit quality was measured using nondestructive and destructive parameters, including fruit weight, size, percent of red color, bitter pit incidence, starch index, soluble solid concentration (SSC), and firmness. Fruit size was measured using an electronic caliper and fruit weight using a precision scale (Mettler-Toledo, LLC, Columbus, OH). Red color coverage was determined using the Washington State Tree Fruit Research Commission color scale for 'Honeycrisp' (Hanrahan and Mendoza, 2012), with values ranging from 1 ( $0 \%$ to $25 \%$ coverage) to 4 ( $76 \%$ to $100 \%$ coverage). The starch index was determined from the bottom half of each apple after being sprayed with Lugol's solution $\left(15 \mathrm{~g} \cdot \mathrm{L}^{-1}\right.$ potassium iodine and $6 \mathrm{~g} \cdot \mathrm{L}^{-1}$ elemental iodine) using a hand-held spray bottle and then left for $10 \mathrm{~min}$. Starch content was then rated on a scale from 1 (almost no coloration of the fruit, meaning high starch content) to 6 (full coloration of the fruit, meaning low starch content) based on visual assessment (Hanrahan, 2012). Fruit firmness was determined with a Fruit Texture Ana- lyzer (Güss Manufacturing Ltd., Strand, South Africa) fitted with an 11-mm probe, and SSC was determined with a digital refractometer (PAL-1; Atago Inc., Bellevue, WA).

Mineral nutrient analysis. In 2017, five fully developed leaves, five $15-\mathrm{cm}$ long vegetative shoots, and three lateral root sections $\approx 15 \mathrm{~cm}$ long were collected from each replicate at the end of the experiment in September. Roots and leaves were carefully washed using tap water to remove soil and remaining dust or foliar fertilizer residue. Root, stem, and leaf samples were then dried in a chamber with constant air flow at $25{ }^{\circ} \mathrm{C}$ for $30 \mathrm{~d}$. Once dry, leaf samples were ground into a fine powder using a VWR highthroughput homogenizer (VWR, Radnor, PA). For stems and roots, samples were initially ground to $40-\mu \mathrm{m}$ size using a Wiley Mini mill (Thomas Scientific LLC, Swedesboro, $\mathrm{NJ}$ ) and then ground to submicron size using a VWR high-throughput homogenizer (VWR, Radnor, PA). Fruit samples were collected at harvest by taking a longitudinal core from each apple that was previously used for fruit-quality assessment and pooled into a composite sample for each replicate. Samples were then dried at $60{ }^{\circ} \mathrm{C}$ for $3 \mathrm{~d}$ and ground into fine powder using a mortar and pestle. Then $200 \mathrm{mg}$ of roots, stems, leaves, and fruit were weighed into PTFE tubes, and acid digested using $6 \mathrm{~mL}$ of $\mathrm{HNO}_{3}$. After digestion, the solutions were filtered with a 0.45 - $\mu \mathrm{m}$ PTFE filter (Thermo Fisher Scientific, Waltham, MA). Filtered digests were then diluted $100 \times$ and analyzed using an Agilent 4200 microwave plasma-atomic emission spectrometer (MP-AES) (Agilent, Santa Clara, CA) and then run in combination with calcium, potassium, and magnesium ICP standards for validation (Kalcsits, 2016). Nitrogen content was determined using a PDZ Europa ANCA-GSL elemental analyzer. Subsequently, stoichiometric ratios of nitrogen to calcium $(\mathrm{N}: \mathrm{Ca})$, potassium to calcium $(\mathrm{K}: \mathrm{Ca})$, magnesium to calcium $(\mathrm{Mg}: \mathrm{Ca})$, and the sum of nitrogen, potassium, and magnesium to calcium $[(\mathrm{N}+\mathrm{K}+\mathrm{Mg}): \mathrm{Ca}]$ in leaves and fruits were calculated.

Tree removal and biomass partitioning. At the end of the 2018 growing season, one whole tree per replicate of water-limited and well-watered treatments, including roots, was carefully removed from the orchard, and then separated into leaves, stems, and roots. Roots were washed using tap water to remove all remaining soil. Trees were then transported to WSU-TFREC and then left to dry in a

Table 1. Soil nutrient availability at the WSU-Sunrise orchard, April 2017. Cation exchange capacity (CEC), organic matter (OM), total bases (T. bases), electrical conductance (EC), base saturation (Base sat.), exchangeable sodium percent (ESP), and estimate nitrogen release (ENR).

\begin{tabular}{|c|c|c|c|c|c|c|c|c|c|c|c|}
\hline $\begin{array}{l}\text { Depth } \\
\text { (cm) }\end{array}$ & $\mathrm{P}(\mathrm{mg} / \mathrm{kg})$ & $\mathrm{K}(\mathrm{mg} / \mathrm{kg})$ & $\mathrm{B}(\mathrm{mg} / \mathrm{kg})$ & $\mathrm{Zn}(\mathrm{mg} / \mathrm{kg})$ & $\mathrm{Mn}(\mathrm{mg} / \mathrm{kg})$ & $\mathrm{Cu}(\mathrm{mg} / \mathrm{kg})$ & $\mathrm{Fe}(\mathrm{mg} / \mathrm{kg})$ & $\mathrm{Ca}(\mathrm{meq} / 100 \mathrm{~g})$ & $\mathrm{Mg}(\mathrm{meq} / 100 \mathrm{~g})$ & $\mathrm{Na}(\mathrm{meq} / 100 \mathrm{~g})$ & $\begin{array}{c}\mathrm{N} \\
(\mathrm{kg} / \mathrm{ha})\end{array}$ \\
\hline 40 & 8.3 & 389 & 0.17 & 2.4 & 2.17 & 0.6 & 9 & 6.3 & 1.7 & 0.05 & 64.3 \\
\hline 20 & 8.9 & 7.1 & 0.13 & 2.5 & 1.9 & 7.7 & 1.4 & 9.2 & 103.3 & 0.8 & 47.7 \\
\hline 40 & 8.7 & 7.1 & 0.11 & 2.5 & 1.6 & 7.3 & 1.1 & 9.1 & 104.5 & 0.6 & 40.7 \\
\hline
\end{tabular}


Table 2. Mean monthly environmental conditions (mean air temperature, relative humidity, and wind speed) from WSU-Sunrise and WSU-TFREC AgWeatherNet weather stations for 2017 and WSU-Sunrise for 2018 for the months April to October.

\begin{tabular}{lccrrr}
\hline & Air temp. $\left({ }^{\circ} \mathrm{C}\right)$ & RH $(\%)$ & Precipitation $(\mathrm{mm})$ & Wind speed $(\mathrm{m} / \mathrm{s})$ \\
\hline May & & & 2017 & & \\
June & 16.3 & 51.0 & & 6.1 & 2.61 \\
July & 20.5 & 40.9 & & 0.0 & 2.20 \\
Aug. & 26.3 & 29.5 & 2.0 & 1.80 \\
& 25.0 & 36.1 & & 2018 & 3.16 \\
May & & & & 11.7 & 3.01 \\
June & 19.9 & 43.6 & 0.0 & 2.89 \\
July & 19.9 & 31.0 & 0.2 & 2.46 \\
Aug. & 26.0 & 38.1 & & & \\
\hline
\end{tabular}
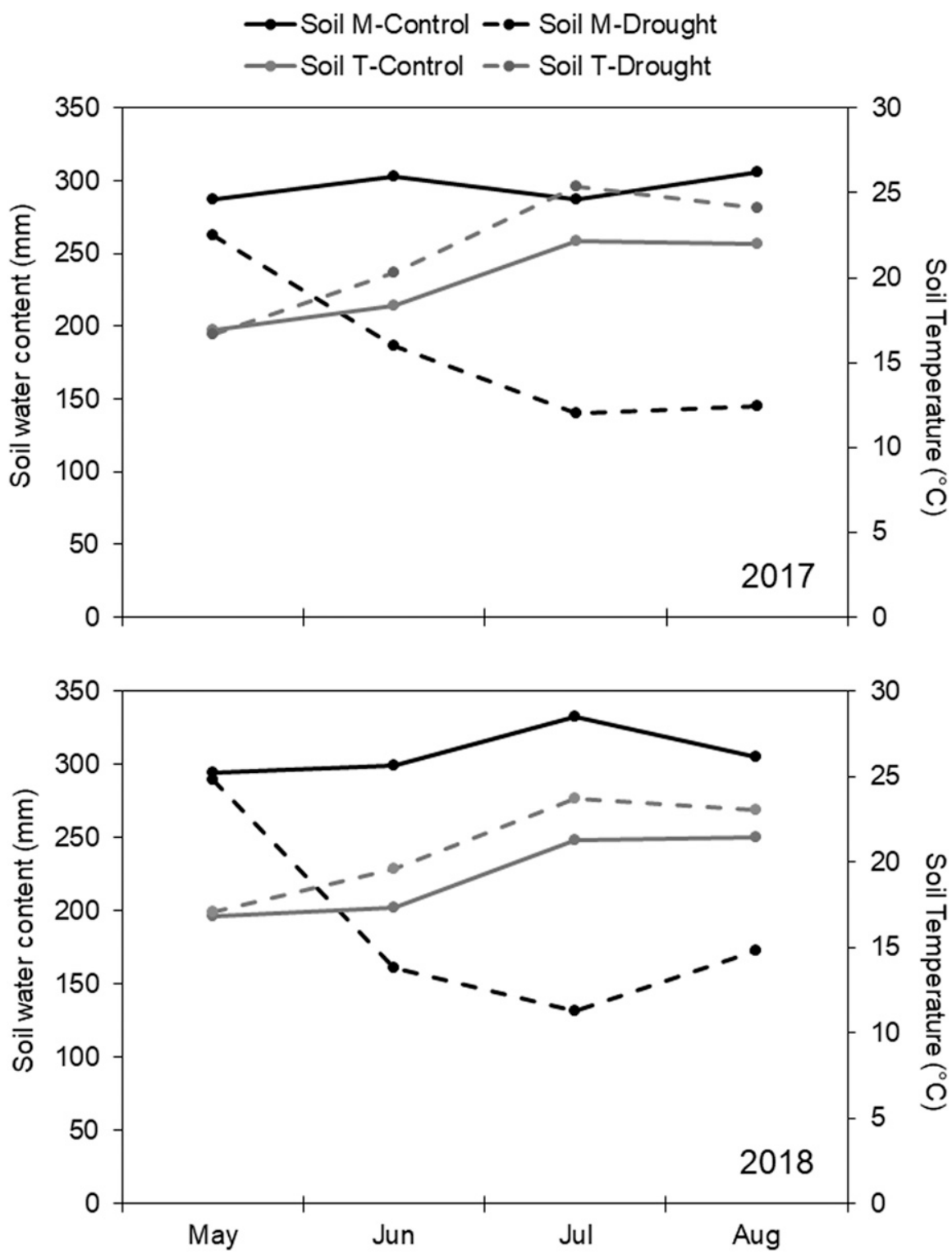

Fig. 1. Average soil moisture $(\mathrm{mm})$ and soil temperature $\left({ }^{\circ} \mathrm{C}\right)$ for well-watered and water-limited trees at WSU-Sunrise experimental orchard for 2017 and $2018(n=6)$.

chamber with constant air flow at $25^{\circ} \mathrm{C}$ for 60 d. Leaves were collected at the time of tree removal, and leaf area was measured using a LI-COR Li-3100C leaf scanner (LI-COR Inc., Lincoln, NE). Once the plant material was dry, sub-samples were ground and digested in nitric acid to analyze for nutrient concentrations as described previously. Ele- mental concentrations were then multiplied by the total dry weight of each plant part to estimate the total plant part nutrient content (mg), and nutrient partitioning was calculated among leaves, stems, and roots.

Data analysis. Data were analyzed by performing an analysis of variance and a Tukey's means separation with a confidence of
95\% (SAS, ver. 9.4 PROC GLM). Nutrient content for leaf, stem, and root data were also analyzed by principal component analysis (SAS, ver. 9.4 PROC FACTOR and Microsoft Excel) and clustering (SAS, ver. 9.4 PROC CLUSTER and PROC TREE). Categorical ordinal variables (percent of red color, starch index, fruit size, and bitter pit incidence) were analyzed using a proportional odds model (SAS, ver. 9.4 PROC LOGISTIC), where the model compares the probability of each rootstock fruit of being in higher levels of the scale (Diaz and Morales, 2009). Using the analysis, we can assign a probability that an individual fruit will belong to each discrete class.

\section{Results}

Soil moisture was reduced to $\approx 50 \%$ of FC for both years of the experiment in the waterlimited treatment, which also increased the soil temperature by $\approx 2{ }^{\circ} \mathrm{C}$ (Fig. 1). Total tree dry weight was significantly lower when water was limited (Fig. 2). 'G.890' had consistently higher leaf, stem, and root dry weight and leaf area than 'G.41', 'M.9', and 'B.9' (Table 3). Moreover, 'B.9' had the lowest dry weight for leaf and stem, while 'G.41' had the lowest root dry weight. Interestingly, 'M.9' and 'B.9' had a higher root:shoot ratio than both Geneva rootstocks (Table 3). 'G.890' was the most affected by water limitations, by which dry weight was $\approx 30 \%$ lower than the control, followed by 'G.41' and 'B.9', which were $25 \%$ lower, and lastly, dry weight was only $20 \%$ lower for 'M.9' compared with the fully watered controls (Fig. 2).

In 2017, nitrogen content was two times greater in both roots and stems when water limitations were applied compared with the control (Table 4). However, nitrogen content in leaf tissue was unaffected by water limitations. In 2018, water limitations did not affect nitrogen content in any of the tissues that were sampled. In contrast, rootstocks affected nitrogen content in leaves in 2017. Nitrogen content was significantly higher in leaves for 'M.9' than 'G.890' (but not than 'B.9' and 'G.41'). However, in 2018, 'B.9' had higher leaf nitrogen content than 'G.890'. Additionally, 'B.9' had higher root nitrogen content than 'G.41', 'G.890', and 'M.9' and higher stem nitrogen content than 'G.890' and 'M.9' in 2018 (Table 4). For calcium content in 2017, 'G.890' had significantly lower calcium content in the roots than 'G.41', 'M.9', and 'B.9' but there was no effect of rootstocks on stem or on leaf calcium content. Additionally, 
irrigation treatments had no effect on calcium content in any tree organ. In 2018 , calcium content was unaffected by water limitations or rootstock (Table 4).
In 2017, 'B.9' had lower potassium content in stems than 'M.9'. Similarly, in 2018, 'B.9' had lower stem potassium content than 'G.890' and 'M.9. 'B.9' had lower potassium

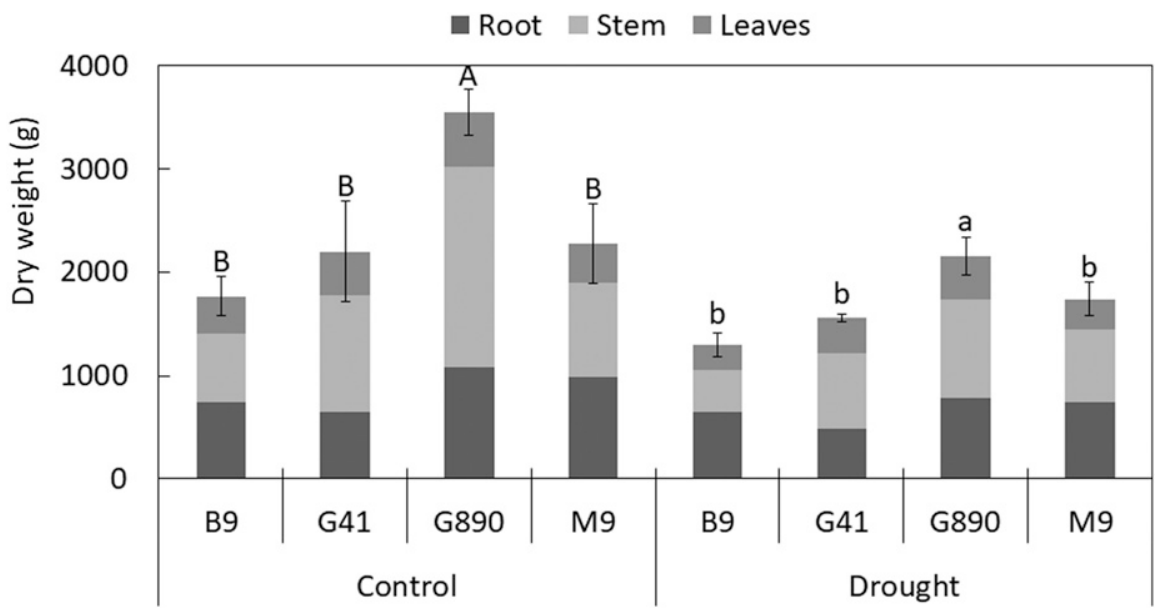

Fig. 2. Total dry weight of 3-year-old 'Honeycrisp' apple trees grafted on 'B.9', 'G.41', 'G.890', and 'M.9' rootstocks under two irrigation treatments. Error bars denote standard error $(n=3)$. Letter case difference accounts for significant differences between treatments, and different letters account for significant differences among rootstocks. Means determined using a Tukey's mean separation test $(\alpha=$ $0.05)(\mathrm{n}=3)$. content in leaves compared with the other three rootstocks, while 'G.41' and 'G.890' had the highest potassium content in leaves for both 2017 and 2018 (Table 4). In 2018, water-limited trees had higher potassium content in stems than trees that were fully watered. Magnesium content in 2017 in leaves was higher from trees that were water limited compared with control trees. Rootstock also affected magnesium content in both stems and leaves, where 'B.9' had lower magnesium content in stems than ' $\mathrm{G} .41$ ' and 'M.9', and 'G.41' had lower magnesium content in leaves than 'M.9'. In 2018, magnesium content was unaffected by water limitations or rootstock genotype (Table 4). Leaf elemental ratios, including potassium to calcium $(\mathrm{K}: \mathrm{Ca})$, nitrogen to calcium $(\mathrm{N}: \mathrm{Ca})$, magnesium to calcium ( $\mathrm{Mg}: \mathrm{Ca})$, and the sum of nitrogen, potassium, and magnesium to calcium $(\mathrm{K}+\mathrm{N}+\mathrm{Mg}: \mathrm{Ca})$ in the leaf were unaffected by irrigation treatment or rootstocks in either year (data not shown).

The large differences in biomass between well-watered and water-limited trees strongly contributed to differences in overall total nutrient content. Well-watered trees had more total nitrogen and magnesium in leaves than trees that were water-limited (Table 5).

Table 3. Root, stem and leaf biomass ( $\mathrm{g}$ dry weight), total leaf area $\left(\mathrm{cm}^{2}\right)$, and root:shoot biomass ratio ( \pm standard error; $\left.\mathrm{n}=3\right)$ for 'Honeycrisp' apple grafted on 'B.9', 'G.41', 'G.890', and 'M.9' rootstock genotypes under two irrigation treatments. Changes in letter case indicates significant differences between the two irrigation treatments; and different letters denote significant differences among rootstocks within irrigation treatments, determined using a Tukey's mean separation test $(\alpha=0.05)$. Values at the bottom correspond to the $P$ values for each factor and interactions between them. Bold numbers represent $P$ values $<$ 0.05 .

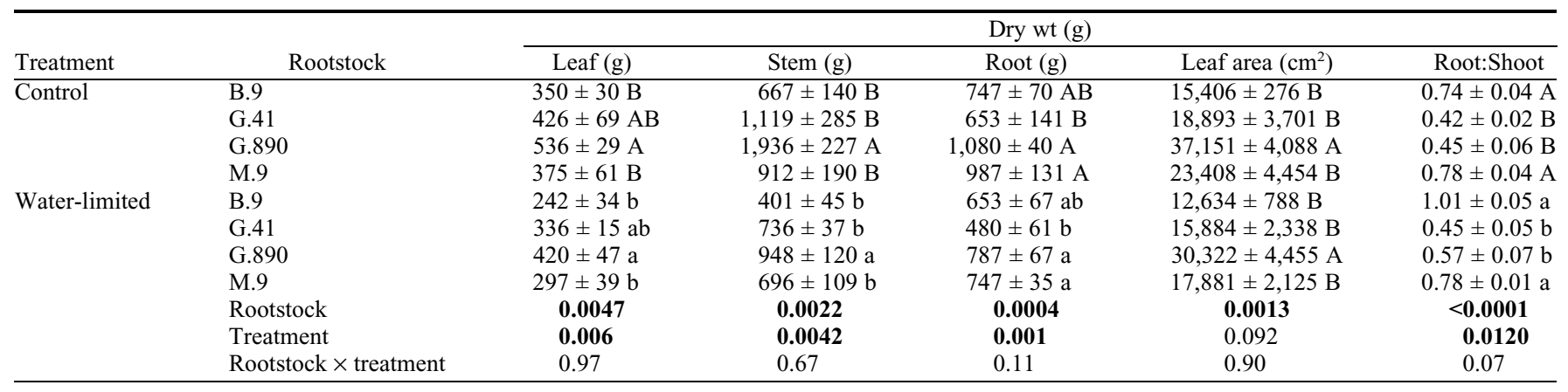

Table 4. Nitrogen, calcium, potassium, and magnesium content (mg/g) for roots, stems, and leaves of 'Honeycrisp' apple. Pooled means were used for 'B.9', 'G.41', 'G.890', and 'M.9' rootstocks and the two irrigation treatments because there were no significant interactions between the two factors. Rootstock or treatment means within rows and years followed by common letters were not different $(\alpha=0.05)$ and were determined by a Tukey's test $(n=3)$.

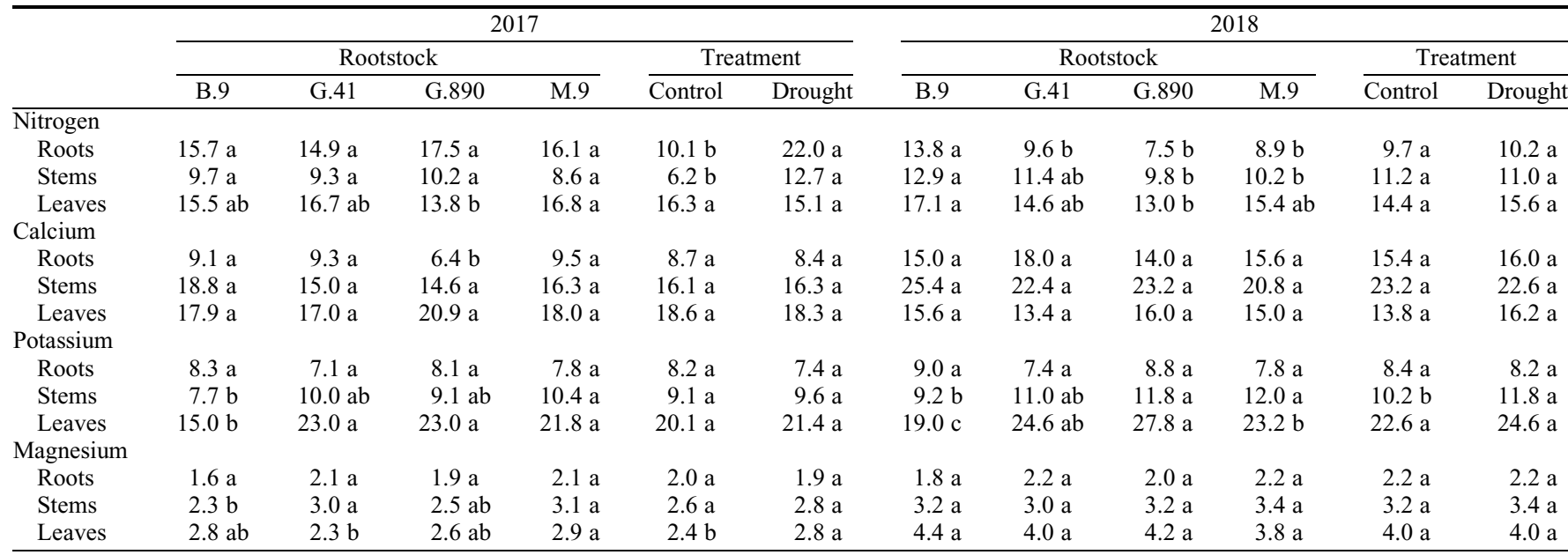


Table 5. Nitrogen, calcium, potassium, and magnesium total content (mg) for roots, stems, and leaves of 'Honeycrisp' apple. Pooled means were used for 'B.9', 'G.41', 'G.890', and 'M.9' rootstocks and the two irrigation treatments because there were no significant interactions between the two factors. Rootstock or treatment means within rows, and years followed by common letters were not different $(\alpha=0.05)$ and were determined by a Tukey’s test $(\mathrm{n}=3)$.

\begin{tabular}{|c|c|c|c|c|c|c|}
\hline & \multicolumn{4}{|c|}{ Rootstock } & \multicolumn{2}{|c|}{ Treatment } \\
\hline & B.9 & G.41 & G.890 & M.9 & Control & Drought \\
\hline \multicolumn{7}{|l|}{ Nitrogen } \\
\hline Roots & $9,660 \mathrm{a}$ & $5,509 \mathrm{~b}$ & $7,046 \mathrm{ab}$ & $7,706 \mathrm{ab}$ & $8,262 \mathrm{a}$ & $6,699 a$ \\
\hline Stems & $7,001 \mathrm{~b}$ & $11,291 \mathrm{ab}$ & $14,098 \mathrm{a}$ & $7,966 \mathrm{~b}$ & $12,500 \mathrm{a}$ & $7,349 \mathrm{~b}$ \\
\hline Leaves & $5,011 \mathrm{a}$ & $5,575 \mathrm{a}$ & $6,139 a$ & $4,989 \mathrm{a}$ & $5,931 \mathrm{a}$ & $4,927 \mathrm{~b}$ \\
\hline \multicolumn{7}{|l|}{ Calcium } \\
\hline Roots & $10,491 \mathrm{a}$ & $10,156 \mathrm{a}$ & $12,711 \mathrm{a}$ & $13,528 \mathrm{a}$ & $12,932 \mathrm{a}$ & $10,511 \mathrm{~b}$ \\
\hline Stems & $13,713 \mathrm{~b}$ & $20,696 \mathrm{~b}$ & $32,100 \mathrm{a}$ & $16,776 \mathrm{~b}$ & $25,783 \mathrm{a}$ & $15,859 \mathrm{~b}$ \\
\hline Leaves & $4,498 \mathrm{~b}$ & $5,127 \mathrm{ab}$ & $7,332 \mathrm{a}$ & $4,808 \mathrm{~b}$ & $5,728 \mathrm{a}$ & $5,154 \mathrm{a}$ \\
\hline \multicolumn{7}{|l|}{ Potassium } \\
\hline Roots & $6,370 \mathrm{ab}$ & $4,273 \mathrm{~b}$ & $8,108 \mathrm{a}$ & $6,872 \mathrm{ab}$ & $7,275 \mathrm{a}$ & $5,537 \mathrm{~b}$ \\
\hline Stems & $4,780 \mathrm{c}$ & $9,931 \mathrm{~b}$ & $15,991 \mathrm{a}$ & $9,707 \mathrm{bc}$ & $11,730 \mathrm{a}$ & $8,475 \mathrm{~b}$ \\
\hline Leaves & $5,531 \mathrm{c}$ & $9,284 \mathrm{~b}$ & $13,272 \mathrm{a}$ & $7,837 \mathrm{bc}$ & $9,780 \mathrm{a}$ & $8,181 \mathrm{a}$ \\
\hline \multicolumn{7}{|l|}{ Magnesium } \\
\hline Roots & $1,332 \mathrm{ab}$ & $1,277 \mathrm{~b}$ & $1,919 \mathrm{ab}$ & $2,018 \mathrm{a}$ & $1,839 \mathrm{a}$ & $1,434 \mathrm{~b}$ \\
\hline Stems & $1,729 \mathrm{~b}$ & $2,768 \mathrm{~b}$ & $4,509 \mathrm{a}$ & $2,674 \mathrm{~b}$ & $3,587 \mathrm{a}$ & $2,253 \mathrm{~b}$ \\
\hline Leaves & $1,240 \mathrm{~b}$ & $1,506 \mathrm{ab}$ & $1,995 \mathrm{a}$ & $1,267 \mathrm{~b}$ & $1,707 \mathrm{a}$ & $1,297 \mathrm{~b}$ \\
\hline
\end{tabular}
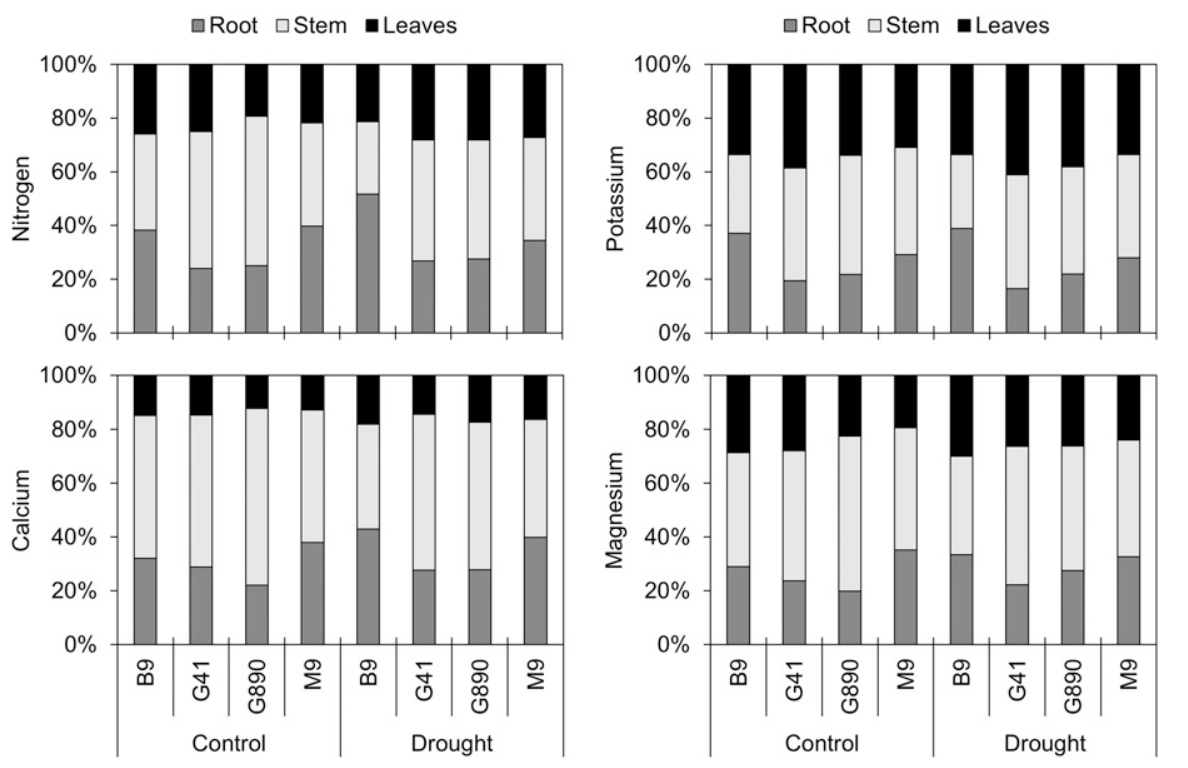

Fig. 3. Total tree nitrogen, calcium, potassium, and magnesium partitioning (\%) between roots, stems, and leaves for 'Honeycrisp' apple grafted on 'B.9', 'G.41', 'G.890', and 'M.9' rootstocks genotypes under two irrigation treatments $(\mathrm{n}=3)$.

Total nitrogen, calcium, potassium, and magnesium were all higher in stems and, except for total nitrogen, in roots of well-watered trees. 'G.890' had higher total nitrogen, calcium, potassium, and magnesium in leaves and stems compared with the other rootstocks (Table 5). However, 'B.9' had the highest total root nitrogen, and 'M.9' had the highest total root magnesium than 'G.41'. Because of differences in biomass partitioning, 'B.9' and 'M.9' had the lower total nutrient content in stems and leaves, while 'G.41' generally had the lowest total nutrient content in the roots (Table 5).

Although there were differences in biomass partitioning between treatments, water limitations did not affect overall nutrient partitioning among roots, stems, and leaves. Nonetheless, there was a rootstock effect on nutrient partitioning where partitioning of nitrogen, calcium, potassium, and magnesium to the roots was consistently higher for
'B.9' compared with 'G.890' and 'G.41' (Fig. 3). Conversely, nutrient partitioning to the stems was the lowest for 'B.9'; while 'G.41' and 'G.890', which accumulated more stem biomass, had the highest partitioning for all nutrients to the stems. Only calcium and nitrogen partitioning in stems and roots were affected by water limitations. Water-limited trees had higher calcium partitioning to the roots than the control, and 'M.9' and 'B.9' had higher proportions of calcium allocated to roots than 'G.41' and 'G.890'. Nitrogen had a significant interaction between rootstocks and irrigation treatments, where only 'B.9' had higher nitrogen in the roots when under water limitations. However, calcium and nitrogen partitioning to the stems was higher for the fully watered control compared with water-limited trees (Fig. 3). There were significant relationships between calcium and other mineral nutrients, particularly calcium and nitrogen in leaves (Supplemental Fig. 1), and calcium and potassium or magnesium in stems (Supplemental Fig. 2) and roots (Supplemental Fig. 3). Nitrogen in leaves was not correlated to nitrogen content in stems and roots (Supplemental Table 1). However, calcium and magnesium were correlated among plant fractions.

Rootstock genotype influenced fruit size and weight in 2018 and 2019. Fruit from 'G. 890 ' trees weighed more and had larger average diameter than fruit from 'B.9' trees. (Table 6). In 2019, fruit harvested from trees on 'G.890' had higher soluble solids content (SSC) than 'B.9' and 'G.41' (Table 6). The number of fruit per tree was also significantly greater for 'G.890' in 2018 but was greater for 'M.9' and 'B.9' in 2019.

Rootstocks 'B.9' and 'M.9' had a lower probability of bitter pit incidence than ' $\mathrm{G} .41$ ' and 'G.890' in both years (Fig. 4). 'G.890' had lower probability of red color coverage than 'M.9' and 'B.9' in 2018, and 'G.41' had a higher probability of having fruit with more red color coverage than 'B.9', 'M.9', and 'G.890' in 2019 (Fig. 5). The probability for starch degradation score had no differences among rootstocks for 2018 but was greater for 'G.41' than 'G.890' in 2019 (Fig. 6). For both years, regardless of crop load, 'G.890' had the highest probability of having fruits in the higher values of the sizing scale, while 'B.9' had the least (Fig. 7). 'G.890' had significantly higher fruit potassium content than 'M.9' and 'B.9' in 2018, while in 2019 'G.890' and 'G.41' had higher potassium than 'M.9' and 'B.9'. 'G.41' had higher fruit magnesium content than 'M.9' and 'B.9' in both years (Table 7). Fruit calcium content and potassium-to-calcium ratio were not different among rootstocks either years. However, there was a significant linear relationship ( $P=0.019$ ) between bitter pit incidence and potassium-to-calcium ratio, which indicates and clearly shows the separation between 'M.9' and 'B.9' rootstocks with 'G.41' and 'G.890' (Supplemental Fig. 4).

Through a principal component analysis followed by clustering for nutrient 
Table 6. Fruit quality parameters, number of fruit per tree, fruit diameter (mm), fruit weight (g), fruit firmness (kg), and fruit soluble solids content (SSC) for 'Honeycrisp' apple grafted on 'B.9', 'G.41', 'G.890', and 'M.9' rootstocks genotypes. Different letters denote significant differences among rootstocks, determined using a Tukey’s mean separation test $(\alpha=0.05)(\mathrm{n}=3)$.

\begin{tabular}{|c|c|c|c|c|c|}
\hline Rootstock & Fruit/tree & Fruit diam (mm) & Fruit wt (g) & Fruit firmness (kg) & Fruit SSC (\%) \\
\hline \multicolumn{6}{|c|}{2018} \\
\hline B.9 & $10.3 \pm 1.1 \mathrm{~b}$ & $90.8 \pm 1.2 b$ & $307 \pm 12 b$ & $7.7 \pm 0.1 \mathrm{a}$ & $14.3 \pm 0.2 \mathrm{a}$ \\
\hline G.41 & $10.4 \pm 1.2 \mathrm{~b}$ & $93.2 \pm 1.6 \mathrm{ab}$ & $342 \pm 15 \mathrm{ab}$ & $6.9 \pm 0.2 \mathrm{~b}$ & $14.8 \pm 0.3 \mathrm{a}$ \\
\hline G.890 & $16.1 \pm 2.2 \mathrm{a}$ & $95.2 \pm 1.0 \mathrm{a}$ & $346 \pm 10 \mathrm{a}$ & $7.3 \pm 0.2 \mathrm{ab}$ & $14.4 \pm 0.2 \mathrm{a}$ \\
\hline M.9 & $14.2 \pm 1.0 \mathrm{ab}$ & $92.1 \pm 0.9 \mathrm{ab}$ & $328 \pm 8 \mathrm{ab}$ & $7.8 \pm 0.2 \mathrm{a}$ & $14.2 \pm 0.2 \mathrm{a}$ \\
\hline \multicolumn{6}{|c|}{2019} \\
\hline B.9 & $35 \pm 3.8 \mathrm{a}$ & $83.9 \pm 1.1 \mathrm{~b}$ & $232 \pm 9 \mathrm{c}$ & $6.6 \pm 0.1 \mathrm{ab}$ & $11.9 \pm 0.2 \mathrm{~b}$ \\
\hline G.41 & $19.1 \pm 2.0 \mathrm{~b}$ & $91.8 \pm 0.9 \mathrm{a}$ & $305 \pm 10 \mathrm{ab}$ & $6.6 \pm 0.1 \mathrm{ab}$ & $12.0 \pm 0.3 \mathrm{~b}$ \\
\hline G.890 & $17.1 \pm 3.7 \mathrm{~b}$ & $92.8 \pm 1.1 \mathrm{a}$ & $231 \pm 11 \mathrm{a}$ & $6.9 \pm 0.1 \mathrm{a}$ & $13.4 \pm 0.3 \mathrm{a}$ \\
\hline M.9 & $41.1 \pm 4.0 \mathrm{a}$ & $89.1 \pm 1.2 \mathrm{a}$ & $279 \pm 11 b$ & $6.4 \pm 0.1 \mathrm{~b}$ & $12.6 \pm 0.2 \mathrm{ab}$ \\
\hline
\end{tabular}

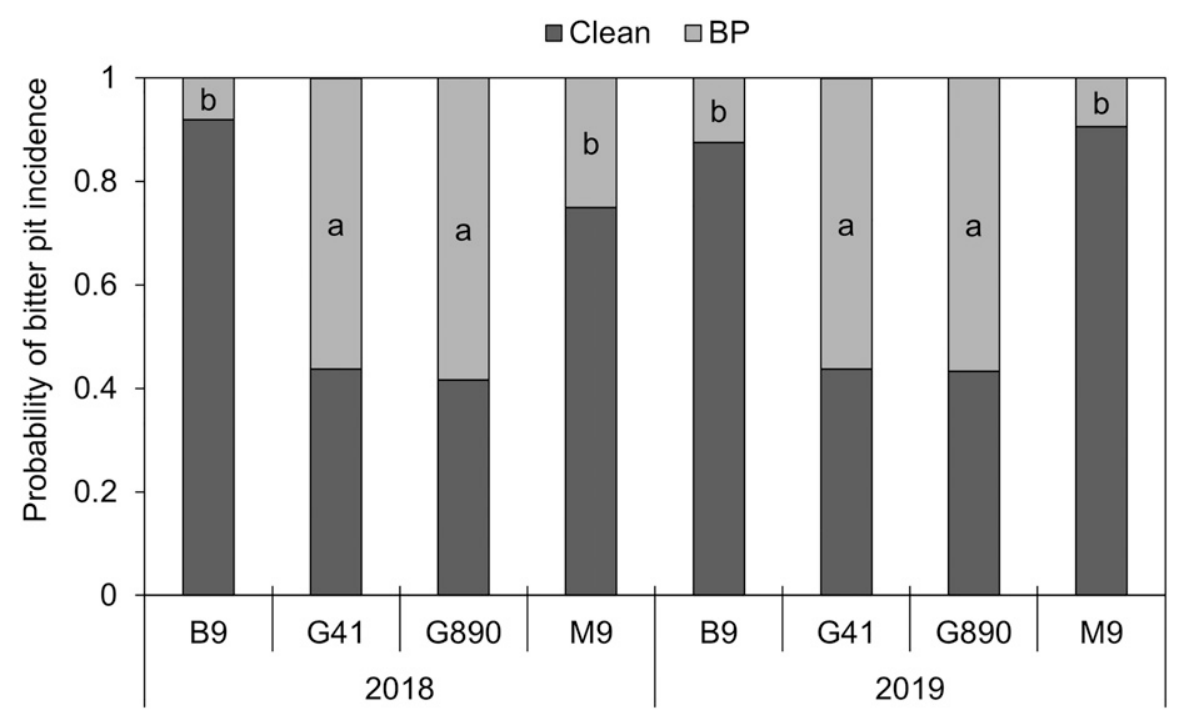

Fig. 4. Probability of the occurrence of bitter pit in fruit at harvest for 'Honeycrisp' apple grafted on 'B.9', 'G.41', 'G.890', and 'M.9' rootstocks genotypes. Different letters account for significant differences among rootstocks $(\alpha=0.05)(\mathrm{n}=3)$.

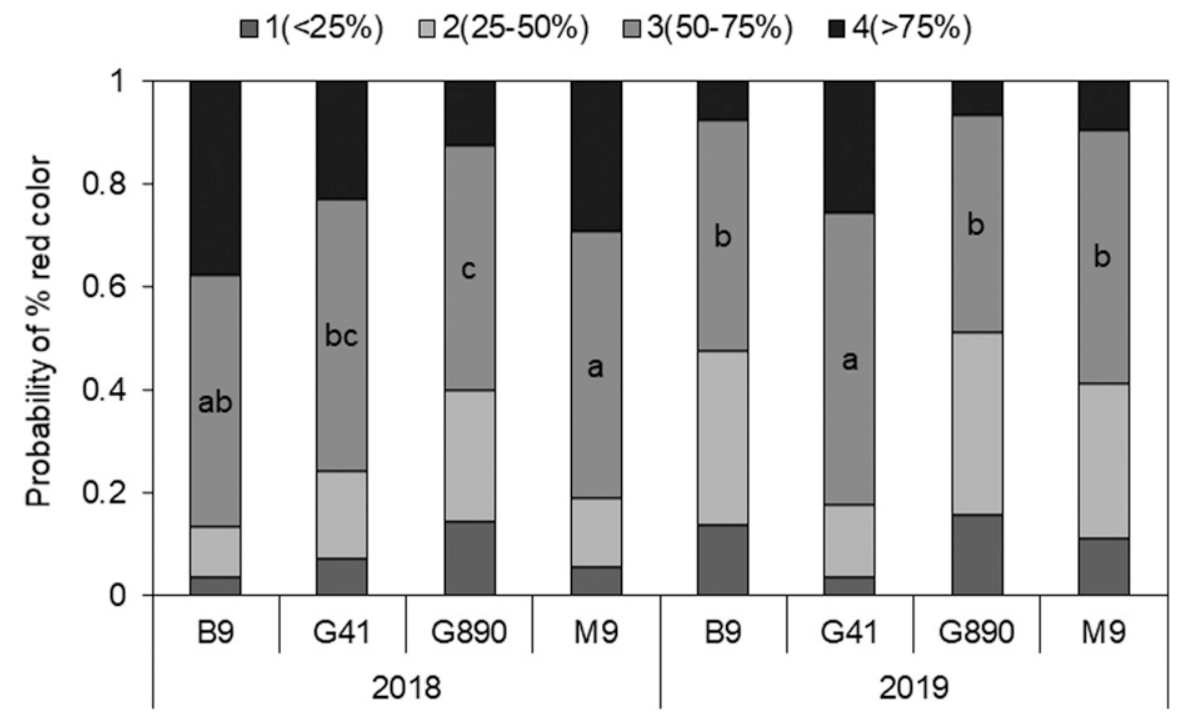

Fig. 5. Probability of occurrence of red color development in fruit at harvest for 'Honeycrisp' apple grafted 'B.9', 'G.41', 'G.890', and 'M.9' rootstocks genotypes. Different letters account for significant differences among rootstocks $(\alpha=0.05)(\mathrm{n}=3)$.

partitioning to leaf, stem, and roots for the different rootstocks and by irrigation treatments, we found that more than $60 \%$ of the data were represented by component 1 , which and 'G.890' were. Moreover, component 2, which represents about $20 \%$ of the data, was more closely related to nutrient partitioning to the leaves. We found that 'G.41' and 'B.9' were unaffected by irrigation treatment, while 'G.890' and 'M.9' were. The cluster analysis showed that when water-limited, nutrient partitioning was similar between 'G.890' and 'G.41'. However, when wellwatered, 'G.890' behaves differently from the rest of the rootstocks. On the other hand, 'B.9', when under well-watered conditions, performed similarly to 'M.9' rootstock for nutrient partitioning. But, when water was limited, it separates from the other rootstocks (Fig. 8).

\section{Discussion}

It is clear that rootstocks can affect tree growth and nutrient partitioning and can also have a significant influence on fruit quality by affecting fruit size, firmness, fruit color, soluble solids content, and maturity (Musacchi and Serra, 2018). Here, we report a strong effect of rootstock on nutrient composition and partitioning as well as overall fruit quality and disorder incidence in 'Honeycrisp' apple. 'G.890' had the largest fruit, and 'B.9' had the smallest. However, 'M.9' and 'G.41' had the fruit with the highest percentage of red color, while 'G.890' had the lowest starch degradation (Table 6, Figs. 5-7). Fruit size and color development are two of the primary considerations in grading fruit, and as such, rootstock would have a major impact on commercial packout. Fallahi (2012) reported similar results for 'Gala' grafted onto different rootstocks. In their study, the most vigorous rootstock, 'Supporter4', had lower color development and lower starch degradation than more dwarfing rootstocks such as 'B.9' and 'M.9'.

Here, 'G.890' and 'G.41' fruit had the highest probability of bitter pit among the rootstocks used, and 'M.9' and 'B.9' had the lowest for both years (Fig. 4). Similarly, bitter pit incidence was previously reported to be lower for 'B.9' and 'M.9', and higher for a rootstock of similar vigor to ' $\mathrm{G} .890$ ' such as 'CG.5087' (Lordan et al., 2019). Conversely, in that study, 'G.41' had low bitter pit incidence for the 3 years reported, while bitter pit was consistently higher for both years of this study. Larger fruit in 
'Honeycrisp' are typically more prone to develop bitter pit, and fruit size is often positively related to rootstock vigor (Autio, 2001; Neilsen and Hampson, 2014; Reid and Kalcsits, 2020; Reig et al., 2018; Rosenberger et al., 2004). Moreover, nutrient ratios have shown to strongly affect bitter pit incidence
(Cheng and Sazo, 2018; Ferguson and Watkins, 1989; Kalcsits et al., 2019), but there were no significant differences among rootstocks for fruit potassium-to-calcium ratios in our study as there were for bitter pit incidence. However, there was a clear, positive relationship between potassium-to-calcium ratio and bitter pit inci-

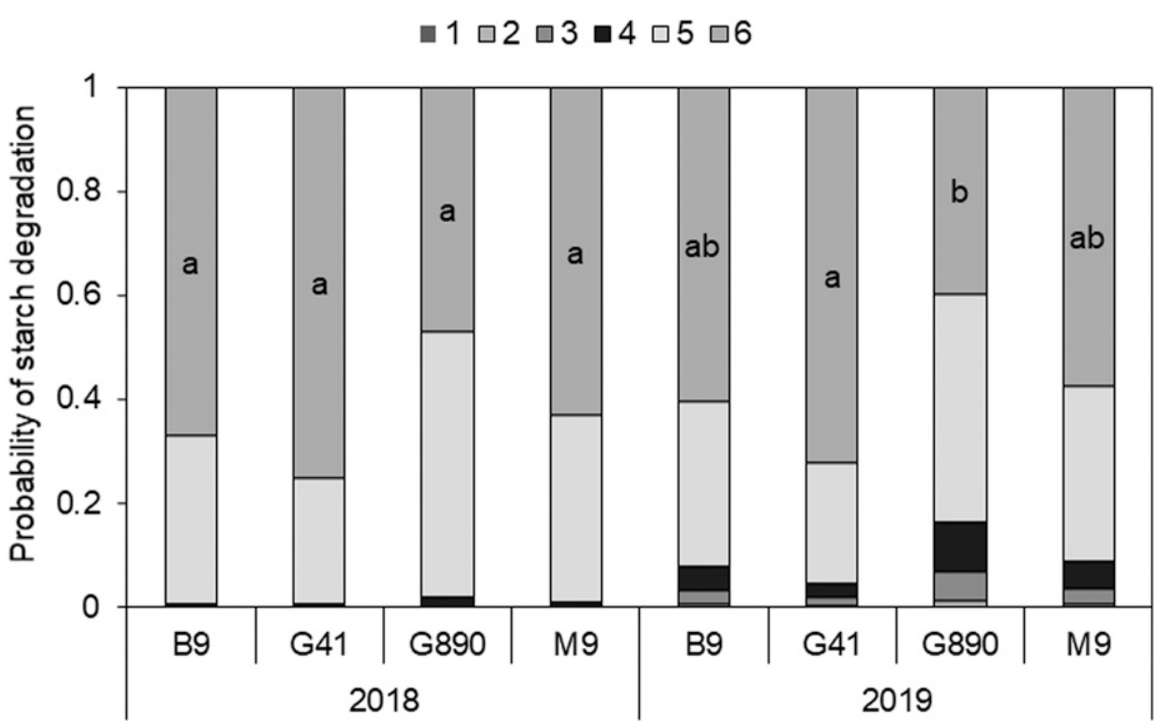

Fig. 6. Probability of occurrence of starch degradation in fruit at harvest for 'Honeycrisp' apple grafted on 'B.9', 'G.41', 'G.890', and 'M.9' rootstocks genotypes. Different letters account for significant differences among rootstocks $(\alpha=0.05)(\mathrm{n}=3)$.

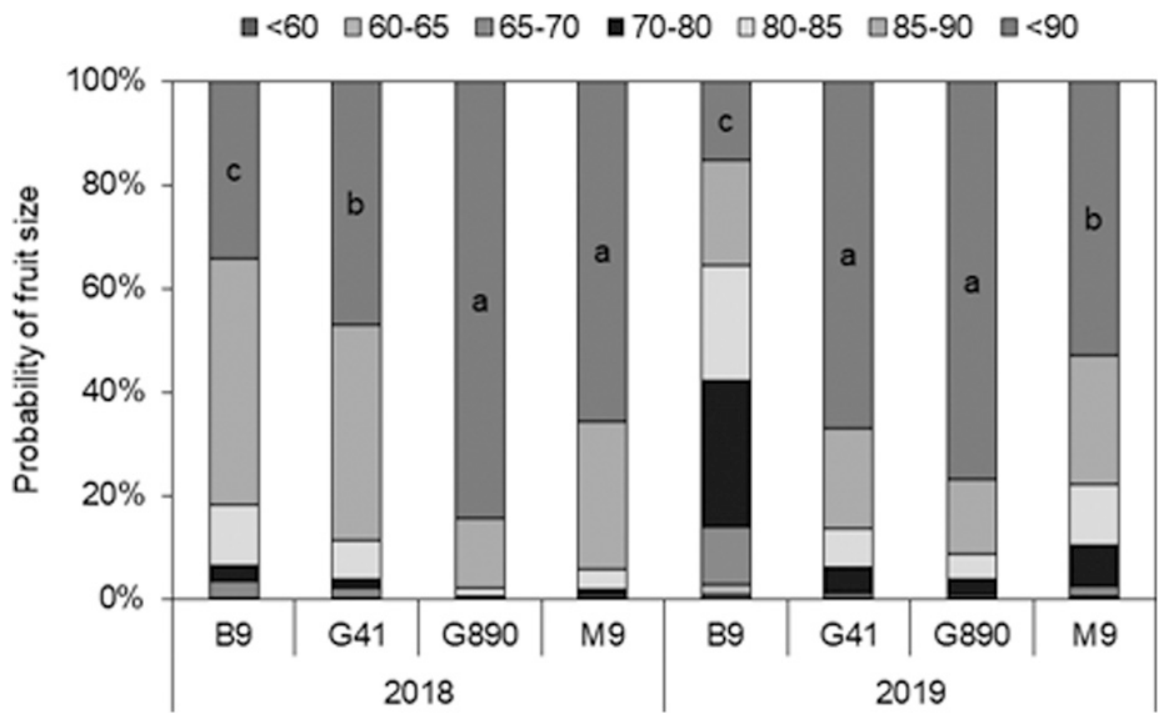

Fig. 7. Probability of fruit diameter classes at harvest for 'Honeycrisp' apple grafted on 'B.9', 'G.41', 'G.890', and 'M.9' rootstocks genotypes. Different letters account for significant differences among rootstocks $(\alpha=0.05)(\mathrm{n}=3)$.

dence like that reported by Fazio et al. (2019) (Supplemental Fig. 4). On the other hand, fruit potassium and magnesium content were higher for both 'G.41' and 'G.890' compared with 'M.9' and 'B.9' in this study. Similarly, Fazio et al. (2019) reported medium and medium-low potassium content for 'B.9' and 'M.9' - while 'G.41' and a similar vigor rootstock to 'G.890', 'B.7-20-21', had medium-to-high fruit potassium content. Likewise, here, we report higher bitter pit incidence for 'G.41' and 'G.890' for both years in addition with larger fruit size than 'B.9' and 'M.9' rootstocks. Smaller fruit size and lower total fruit potassium for 'B.9' and 'M.9' rootstocks could, in part, contribute to the lower bitter pit incidence observed in these rootstocks (Kalcsits et al., 2017; Lordan et al., 2019; Serra et al., 2016). Although some studies were conducted in cooler regions with different growing environments (Fazio et al., 2019; Lordan et al., 2019), differences in fruit nutrient content among rootstock were mostly consistent with those observed here.

The largest impact from water limitations on nutrient dynamics in leaves, stems, and roots was from reduced biomass, and changes to biomass partitioning (Fig. 2) and rootstock also had a significant impact on overall nutrient partitioning (Fig. 3). Moreover, tissue nutrient content was affected by rootstock genotypes and irrigation treatments (Table 4), indicating that changes to water supply or rootstock can affect overall uptake of nutrients from the soil and affect their overall transport and distribution. These differences among rootstocks were reflected in both leaf and fruit elemental content (Tables 4 and 7), which also appear to correspond to observed differences in fruit size and bitter pit incidence. These differences may be correlated with the risk of bitter pit incidence previously reported by Rosenberger et al. (2004) and Cheng and Sazo (2018).

The effect of rootstock on tissue nutrient content was clear in all sampled tissues. The results reported here were like those reported by Lordan et al. (2019) and Reig et al. (2018) where it was shown that a similar size rootstock to 'G.890' - 'CG.5087' - had lower nitrogen concentration, while 'B.9' and 'G.41' had medium-high leaf nitrogen content. Fazio et al. (2019) also reported that 'B.9' had low leaf potassium content; while 'B.67-5-32', similar in size to 'G.890' and 'G.41', had higher leaf potassium content (Lordan et al., 2019; Reig et al., 2018). In a potted study part of this project, 'G.890' had lower root calcium content than 'G.41' (Valverdi et al., 2019); but, in this field study, there were no differences in calcium content among rootstocks. Likewise, Neilsen and Hampson (2014) reported a

Table 7. Fruit nutrient concentration (mg/g) for 'Honeycrisp' apple grafted on 'B.9', 'G.41', 'G.890', and 'M.9' rootstocks genotypes. Different letters denote significant differences among rootstocks, determined using a Tukey's mean separation test $(\alpha=0.05)(\mathrm{n}=3)$.

\begin{tabular}{|c|c|c|c|c|c|c|c|c|}
\hline & $\mathrm{Ca}(\mu \mathrm{g} / \mathrm{g})$ & $\mathrm{K}(\mu \mathrm{g} / \mathrm{g})$ & $\mathrm{Mg}(\mu \mathrm{g} / \mathrm{g})$ & $\mathrm{K} / \mathrm{Ca}$ & $\mathrm{Ca}(\mu \mathrm{g} / \mathrm{g})$ & $\mathrm{K}(\mu \mathrm{g} / \mathrm{g})$ & $\mathrm{Mg}(\mu \mathrm{g} / \mathrm{g})$ & $\mathrm{K} / \mathrm{Ca}$ \\
\hline Rootstock & \multicolumn{4}{|c|}{2018} & \multicolumn{4}{|c|}{2019} \\
\hline G.41 & $20 \mathrm{a}$ & $1,148 \mathrm{ab}$ & $42 \mathrm{a}$ & $67 \mathrm{a}$ & $14 \mathrm{a}$ & $1,268 \mathrm{a}$ & $82 \mathrm{a}$ & $104 \mathrm{a}$ \\
\hline M.9 & $26 \mathrm{a}$ & $1,058 \mathrm{~b}$ & $36 \mathrm{~b}$ & $44 \mathrm{a}$ & $20 \mathrm{a}$ & $970 \mathrm{~b}$ & $56 \mathrm{bc}$ & $53 a$ \\
\hline
\end{tabular}




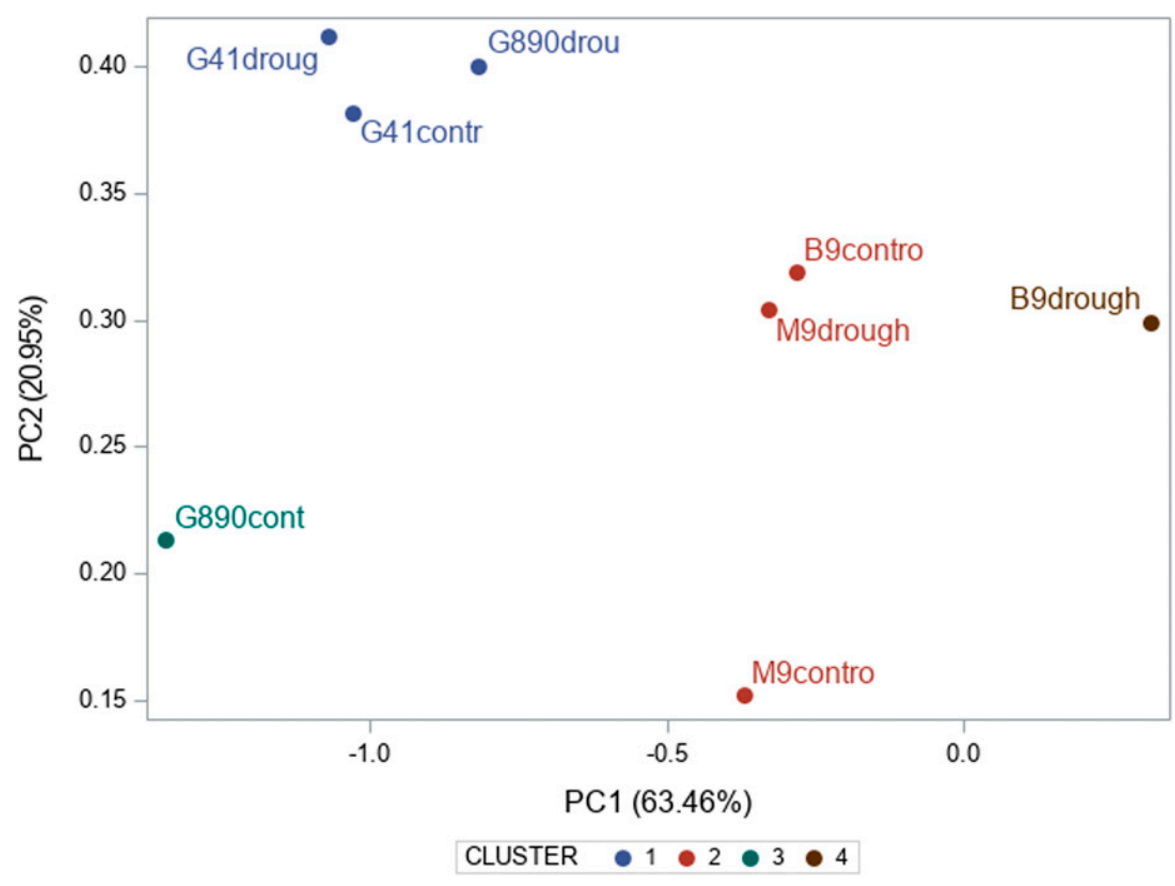

Fig. 8. Principal component analysis for nutrient partitioning to leaves, stems, and roots for Budagovsky-9 (B9), Geneva-41 (G41), Geneva-890 (G890), or M9-T337 (M9) rootstocks exposed to either waterlimited conditions or a well-watered control.

significant correlation between tree vigor and leaf potassium, phosphorus, boron, copper, and calcium. Although our results showed a higher potassium content in the more vigorous rootstocks, this was not the case for calcium content, where there was no apparent vigor effect on leaf calcium content (Table 4). Differences in total leaf calcium content, on the other hand, were more closely aligned with differences in dry weight among the different rootstocks. Total recovered nutrients and content were higher under water-limited conditions in roots and stems but not in leaves. These results are in contrast with previous studies where nutrient content in leaves of water-stressed or nonirrigated trees were higher than trees that were well-watered (Atkinson et al., 1998; Valverdi et al., 2019). Nutrient contents reported here were more aligned with the mineral nutrient values reported in Neilsen and Hampson (2014), research that was also conducted using young 'Honeycrisp' trees and under similar environmental conditions of this study, than those reported in studies conducted on mature 'Honeycrisp' trees and in cooler climates (Cheng and Sazo, 2018; Fazio et al., 2019). This suggests that environment may contribute to above-ground nutrient content and partitioning.

Nutrient partitioning between plant parts such as leaves, stems, and roots indicated differences in how trees allocated and distributed nutrients in the 2 years of this study (Fig. 3). Interestingly, the results shown here differ than those reported using potted trees in Valverdi et al. (2019), in which ' $G .890$ ' had the most partitioning of nutrients to roots and 'B.9' into the stems; while here, 'B.9' partitioned more nutrients to the roots, and 'G.890' and 'G.41' partitioned more nutrients to the stems. Often potted studies are used to understand nutrient or biomass partitioning in many agricultural crops (Alemán et al., 2011; Atkinson et al., 1999; Failla et al., 1992; Verbruggen and Hermans, 2013). Several factors could contribute to differences in allocation and distribution of nutrients between potted and field studies. In these studies, root volume may be limited in potted experiments in contrast to a field experiment, where roots can occupy a greater soil volume. However, in irrigated growing environments, root volumes rarely exceed the watering zone (Hodge et al., 2009; Jones, 2004) and, because drip emitters were used in this experiment, this could have also limited overall root volume.

\section{Conclusions}

Rootstock genotype affected nutrient acquisition and distribution in young 'Honeycrisp' apple trees. Fruit size and bitter pit incidence corresponded to differences in nutrient uptake in addition to the partitioning and distribution of these nutrients among rootstock genotypes. Water-limited trees partitioned more nitrogen and calcium to the roots, while nutrient partitioning to the stems was higher for well-watered trees. Despite the differences in climatic conditions among this and other studies, our results align with those previously reported where more vigorous rootstocks, for example 'G.890', had lower nitrogen and higher potassium concentrations in the leaves; and more dwarfing rootstocks, such as 'B.9', had lower potassium and higher nitrogen concentrations in the leaves. Nonetheless, rootstocks did not show differences in calcium uptake capacity regardless of differences in vigor. Although this study focused on establishment and early production, differences among rootstocks may change with time, and long-term studies will be needed to develop clearer rootstock recommendations for 'Honeycrisp' apple for specific environments.

\section{Literature Cited}

Alemán, F., M. Nieves-Cordones, V. Martínez, and F. Rubio. 2011. Root $\mathrm{K}^{+}$acquisition in plants: The Arabidopsis thaliana model. Plant Cell Physiol. 52(9):1603-1612, doi: 10.1093/pcp/ pcr096.

Atkinson, C.J., M. Policarpo, A.D. Webster, and A.M. Kuden. 1999. Drought tolerance of apple rootstocks: Production and partitioning of dry matter. Plant Soil 206:223-235, doi: 10.1520/ D0850-11.1.

Atkinson, C.J., L. Taylor, J.M. Taylor, and A.S. Lucas. 1998. Temperature and irrigation effects on the cropping, development and quality of 'Cox's Orange Pippin' and 'Queen Cox' apples. Scientia Hort. 75:59-81, doi: 10.1520/ D0850-11.1

Autio, W.R. 2001. Rootstock and scion interact to affect apple tree performance: Results from the 1990 NC-140 cultivar/rootstock trial. Acta Hort. 557:41-46, doi: 10.1520/D0850-11.1.

Autio, W., T. Robinson, S. Blatt, D. Cochran, P. Francescato, E. Hoover, M. Kushad, G. Lang, J. Lordan, D. Miller, I. Minas, R.P. Quezada, M. Stasiak, and H. Xu. 2020. Budagovsky, Geneva, Pillnitz, and Malling apple rootstocks affect 'Honeycrisp' performance over eight years in the 2010 NC-140 'Honeycrisp' apple rootstock trial. J. Amer. Pomol. Soc. 74(4):182195.

Auvil, T. 2016. WSU tree fruit [Online]. Geneva rootstock perform. 2017. 15 Nov. 2020. <http:// treefruit.wsu.edu/news/geneva-rootstockperformance-2016-rootstock-trial update/ $>$.

Bisbis, M.B., N.S. Gruda, and M.M. Blanke. 2019 Securing horticulture in a changing climate $-\mathrm{A}$ mini review. Horticulturae 5(3):56, doi: 10.3390/ horticulturae 5030056.

Casierra-Posada, F., L. F. Cortes, J. Ramirez, and H. C. Franco. 2003. Estado nutricional de arboles de manzano 'Anna' durante la estacion de crecimiento en los altiplanos Colombianos: I. Contenido de elementos minerales. Agron. Colomb. 21:75-82.

Casierra-Posada, F. and L.M. Lizarazo. 2004. Estado nutricional de árboles de manzano 'Anna' durante la estación de crecimiento en los altiplanos Colombianos: II. Relaciones e interacciones entre nutrientes. Agron. Colomb. 22(2):160-169.

Cheng, L. and M.M. Sazo. 2018. Why is 'Honeycrisp' so susceptible to bitter pit? Fruit Quarterly. 26(1):19-23. <http://nyshs.org/wp-content/ uploads/2018/07/Cheng-Pages-from-19-23-NYFQSpring-Book-2018.pdf .

de Freitas, S.T., C.V.T. do Amarante, and E.J. Mitcham. 2015. Mechanisms regulating apple cultivar susceptibility to bitter pit. Scientia Hort. 186:54-60, doi: 10.1016/j.scienta.2015. 01.039 .

Diaz, L. and M. Morales. 2009. Analisis estadistico de datos categoricos. Universidad Nacional de Colombia, Bogota.

Failla, O., G. Zocchi, C. Treccani, and S. Cocucci. 1992. Growth, development and mineral content of apple fruit in different water status conditions. J. Hort. Sci. 67(2):265-271, doi: 10.1520/D0850-11.1.

Fallahi, E. 2012. Influence of rootstock and irrigation methods on water use, mineral nutrition, 
growth, fruit yield, and quality in 'Gala' apple. HortTechnology 22:731-737.

Fallahi, E., W.M. Colt, B. Fallahi, and I.-J. Chun. 2002. The importance of apple rootstocks on tree growth, yield, fruit quality, leaf nutrition, and photosynthesis with an emphasis on 'FUJI'. HortTechnology 12(1):38-44.

Fazio, G., D. Kviklys, M.A. Grusak, and T. Robinson. 2013. Phenotypic diversity and QTL mapping of absorption and translocation of nutrients by apple rootstocks. Asp. Appl. Biol. 119:37-50.

Fazio, G., J. Lordan, M.A. Grusak, P. Francescatto, and T.L. Robinson. 2019. I. Mineral nutrient profiles and relationships of 'Honeycrisp' grown on a genetically diverse set of rootstocks under Western New York climatic conditions. Scientia Hort. 266:108477, doi: 10.1016/j.scienta. 2019.05.004.

Fazio, G., T.L. Robinson, and H.S. Aldwinckle. 2014. Geneva apple rootstocks comparison chart. Center for Technology Licensing, Cornell University, Ithaca, NY. 15 Nov. 2020. $<\mathrm{http}: / /$ www.ctl.cornell.edu/plants/GENEVAApple-Rootstocks-Comparison-Chart.pdf $>$.

Ferguson, I.B. and C.B. Watkins. 1989. Bitter pit in apple fruit. Hort. Rev. 11:289-355.

Gallardo, R.K., I. Hanrahan, Y.A. Hong, and J.J. Luby. 2015. Crop load management and the market profitability of 'Honeycrisp' apples. HortTechnology 25(4):575-584, doi: 10.1016/ S1574-0072(01)10029-0.

Grant, O.M. 2012. Understanding and exploiting the impact of drought stress on plant pgysiology, p. 89-104. In: Abiotic stress responses in plants. Springer, New York, doi: 10.1007/9781-4614-0634-1.

Hanrahan, I. 2012. Starch iodine index Honeycrisp. Washington Tree Fruit Research Commission, West Wenatchee, WA.

Hanrahan, I. and M. Mendoza. 2012. Honeycrisp color classification scale - $\%$ of red. Washington Tree Fruit Research Commission, West Wenatchee, WA.

Hodge, A., G. Berta, C. Doussan, F. Merchan, and M. Crespi. 2009. Plant root growth, architecture and function. Plant Soil 321(1-2):153-187, doi: 10.1007/s11104-009-9929-9.

Jones, H.G. 2004. Irrigation scheduling: Advantages and pitfalls of plant-based methods. J. Expt. Bot. 55(407):2427-2436, doi: 10.1093/ jxb/erh213.

Kalcsits, L., E. Lotze, M. Tagliavini, K.D. Hannam, T. Mimmo, D. Neilsen, G. Neilsen, D. Atkinson, E. Casagrande Biasuz, L. Borruso, S. Cesco, E. Fallahi, Y. Pii, and N.A. Valverdi. 2020. Recent achievements and new research opportunities for optimizing macronutrient availability, acquisition, and distribution for perennial fruit crops. Agronomy 10(11):1738.

Kalcsits, L., J. Mattheis, L. Giordani, M. Reid, and K. Mullin. 2019. Fruit canopy positioning affects fruit calcium and potassium concentrations, disorder incidence, and fruit quality for 'Honeycrisp' apple. Can. J. Plant Sci. 99:761771.

Kalcsits, L., G. van der Heijden, M. Reid, and K. Mullin. 2017. Calcium absorption during fruit development in 'Honeycrisp' apple measured using $44 \mathrm{Ca}$ as a stable isotope tracer. HortScience 52:1804-1809.

Kalcsits, L.A. 2016. Non-destructive measurement of calcium and potassium in apple and pear using handheld $\mathrm{x}$-ray fluorescence. Front. Plant Sci. 7:442, doi: 10.3389/fpls.2016.00442.

Kucukyumuk, Z. and I. Erdal. 2011. Rootstock and cultivar effect on mineral nutrition, seasonal nutrient variation and correlations among leaf, flower and fruit nutrient concentrations in apple trees. Bulg. J. Agr. Sci. 17(5):633-641.

Lordan, J., G. Fazio, P. Francescatto, and T. Robinson. 2017. Effects of apple (Malus $\times$ domestica) rootstocks on scion performance and hormone concentration. Scientia Hort. 225:96-105, doi: 10.1016/j.scienta.2017.06. 050 .

Lordan, J., G. Fazio, P. Francescatto, and T.L. Robinson. 2019. II. Horticultural performance of 'Honeycrisp' grown on a genetically diverse set of rootstocks under Western New York climatic conditions. Scientia Hort. 257:1-10.

Marini, R.P., W.R. Autio, B. Black, J.A. Cline, W Cowgill, R. Crassweller, P. Domoto, C. Hampson, R. Moran, R.A. Parra-Quezada, T. Robinson, M. Stasiak, D.L. Ward, and D. Wolfe. 2012. Summary of the NC-140 apple physiology trial: The relationship between "Golden Delicious' fruit weight and crop density at 12 locations as influenced by three dwarfing rootstocks. J. Amer. Pomol. Soc. 66(2):78-90.

Marini, R.P., B. Black, R.M. Crassweller, P.A. Domoto, C. Hampson, R. Moran, T. Robinson, M. Stasiak, and D. Wolfe. 2014. Performance of 'Golden Delicious' apple on 23 rootstocks at eight locations: A ten-year summary of the 2003 NC-140 dwarf rootstock trial. J. Amer. Pomol. Soc. 68(2):54-68, doi: 10.1520/D085011.1.

Marini, R.P. and G. Fazio. 2018. Apple rootstocks: History, physiology, management, and breeding. Hort. Rev. 45:197-312, doi: 10.1520/ D0850-11.1.
Musacchi, S. and S. Serra. 2018. Apple fruit quality: Overview on pre-harvest factors. Scientia Hort. 234:409-430.

Neilsen, G. and C. Hampson. 2014. 'Honeycrisp' apple leaf and fruit nutrient concentration is affected by rootstock during establishment. J. Amer. Pomol. Soc. 68(4):178-189.

Reid, M. and L. Kalcsits. 2020. Water deficit timing affects physiological drought response, fruit size, and bitter pit development for 'Honeycrisp'apple. Plants 9(7):874.

Reig, G., J. Lordan, G. Fazio, M.A. Grusak, S. Hoying, L. Cheng, P. Francescatto, and T. Robinson. 2018. Horticultural performance and elemental nutrient concentrations on 'Fuji' grafted on apple rootstocks under New York State climatic conditions. Scientia Hort. 227:22-37, doi: 10.1016/j.scienta.2017.07. 002 .

Rosenberger, D.A., J.R. Schupp, S.A. Hoying, L. Cheng, and C.B. Watkins. 2004. Controlling bitter pit in 'Honeycrisp' apples. HortTechnology 14(3):342-349. 9 May 2017. <http://horttech. ashspublications.org/content/14/3/342.short>

Serban, C.F. 2018. Preharvest and postharvest management strategies to reduce bitter pit in 'Honeycrisp' apples. Washington State University, Pullman.

Serra, S., R. Leisso, L. Giordani, L. Kalcsits, and S. Musacchi. 2016. Crop load influences fruit quality, nutritional balance, and return bloom in 'Honeycrisp' apple. HortScience 51(3):236244.

Tworkoski, T. and G. Fazio. 2011. Physiological and morphological effects of size-controlling rootstocks on 'fuji' apple scions. Acta Hort. 903:865-872.

Tworkoski, T. and G. Fazio. 2016. Hormone and growth interactions of scions and sizecontrolling rootstocks of young apple trees. Plant Growth Regulat. 78(1):105-119, doi: 10.1007/s10725-015-0078-2.

Valverdi, N.A., L. Cheng, and L. Kalcsits. 2019. Apple scion and rootstock contribute to nutrient uptake and partitioning under different belowground environments. Agronomy 9(8):415, doi: 10.3390 /agronomy 9080415 .

Verbruggen, N. and C. Hermans. 2013. Physiological and molecular responses to magnesium nutritional imbalance in plants. Plant Soil 368(1-2):87-99, doi: $10.1007 / \mathrm{s} 11104-013-$ 1589-0.

Zandalinas, S.I., R. Mittler, D. Balfagón, V. Arbona, and A. Gómez-Cadenas. 2018. Plant adaptations to the combination of drought and high temperatures. Physiol. Plant. 162(1):2-12, doi: $10.1111 / \mathrm{ppl} .12540$. 


\section{Leaves}

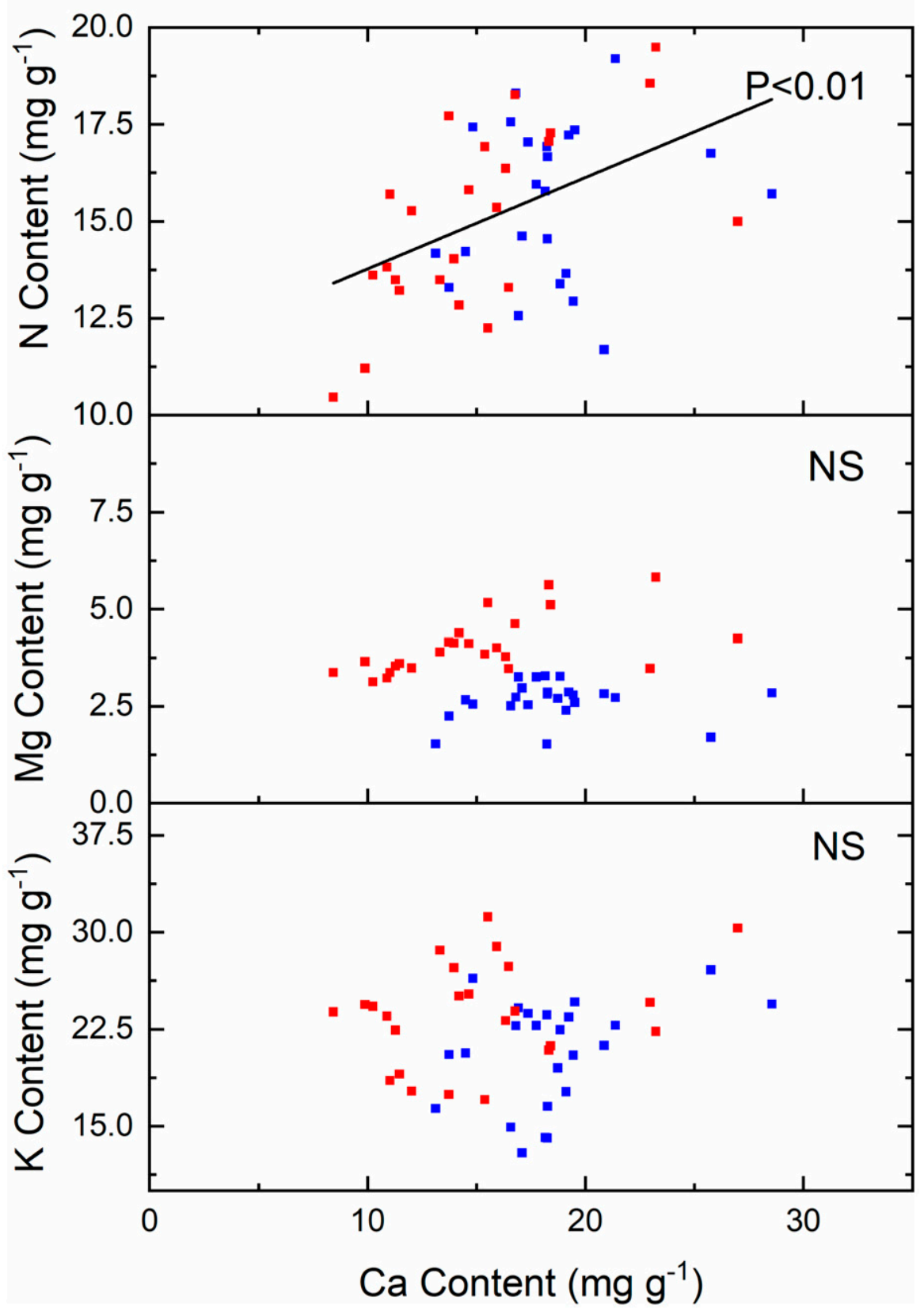

Supplemental Fig. 1. Relationship between Ca content in leaves and $\mathrm{N}$ (upper panel), Mg (middle panel), and K (upper panel) for 2017 (red) and 2018 (blue). Lines represent a significant linear relationship. NS, indicates not significant. 


\section{Stem Tissue}

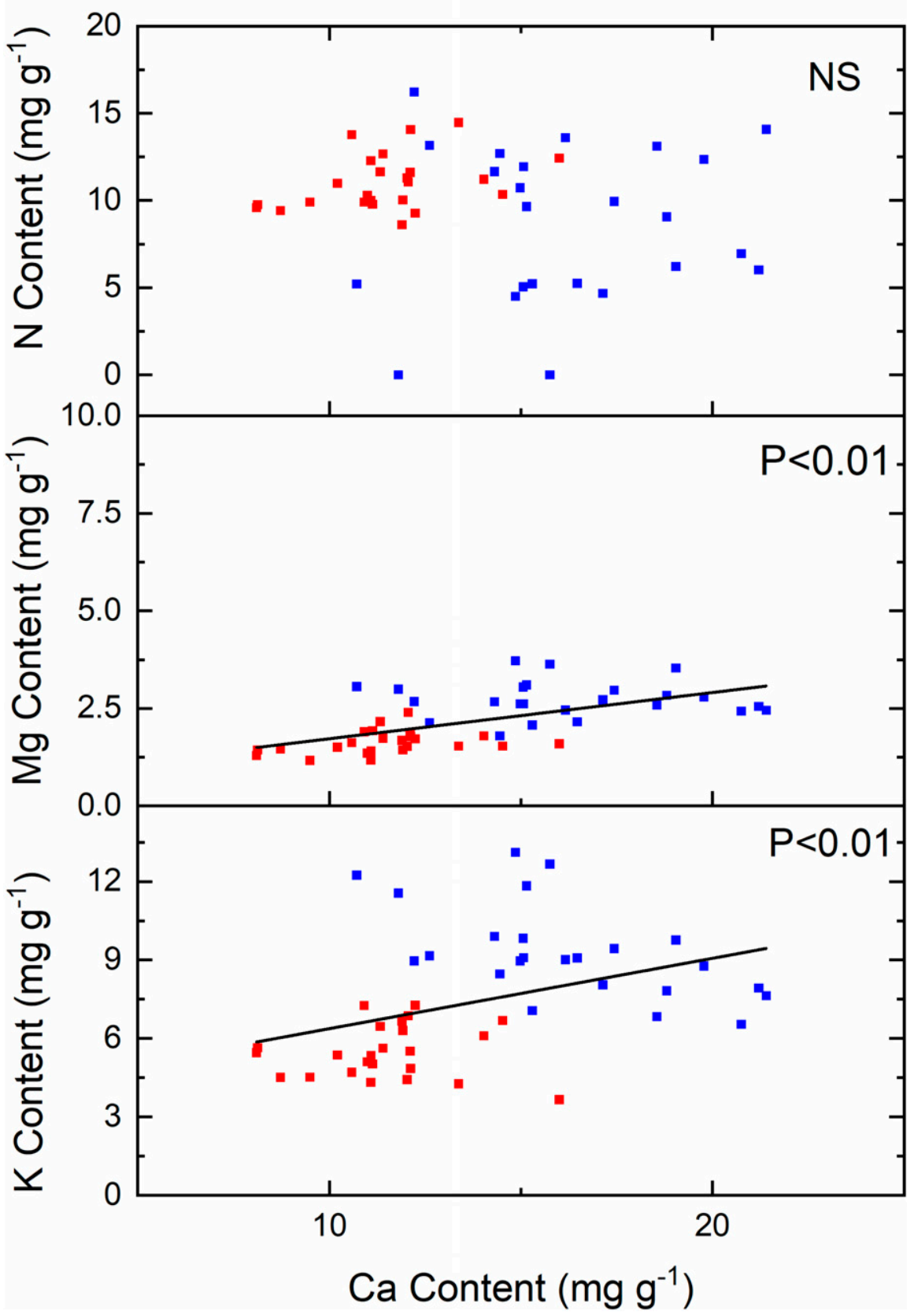

Supplemental Fig. 2. Relationship between Ca content in stem tissue and $\mathrm{N}$ (upper panel), Mg (middle panel), and K (upper panel) for 2017 (red) and 2018 (blue). Lines represent a significant linear relationship. NS, indicates not significant. 


\section{Roots}

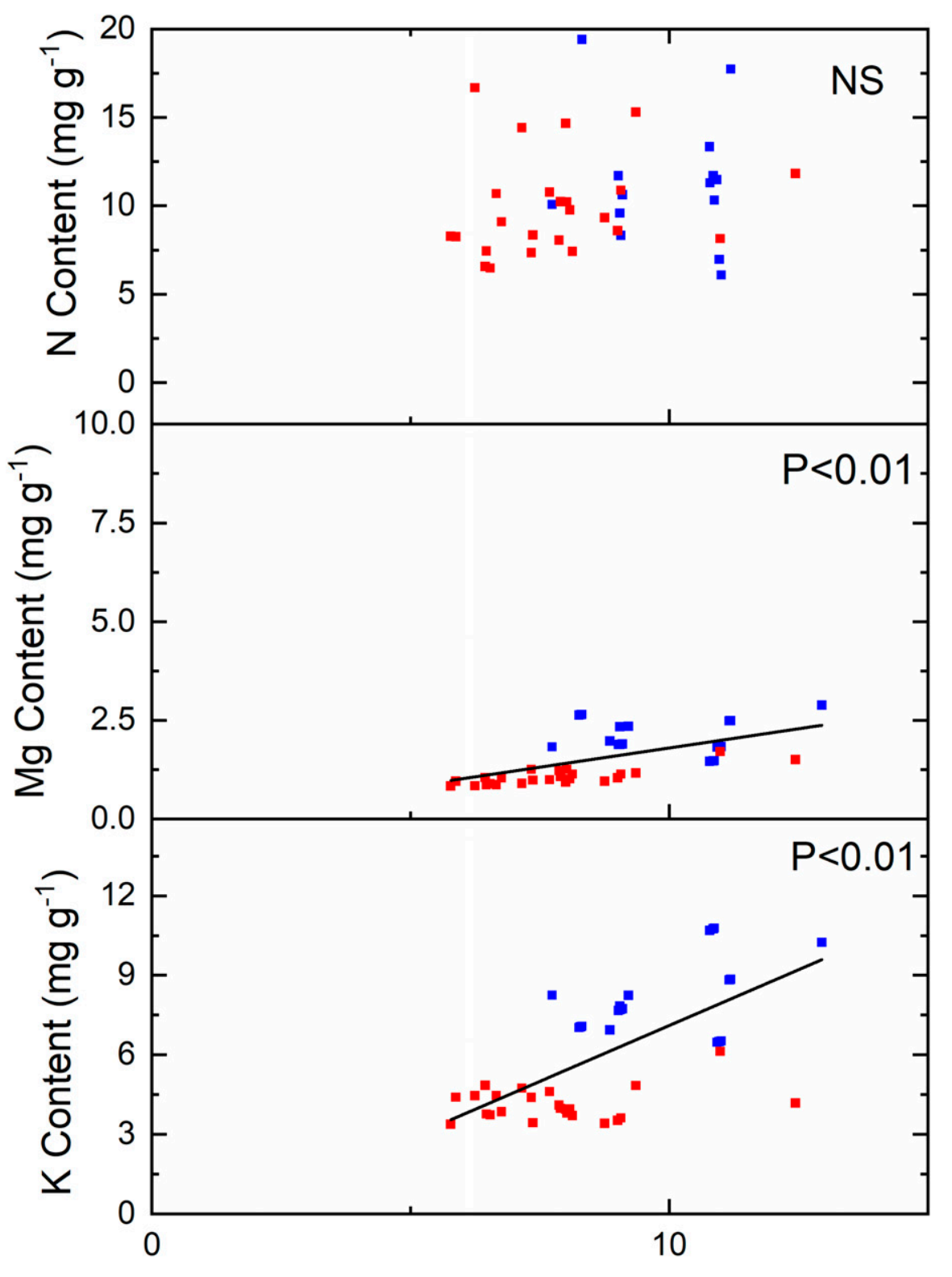

\section{Ca Content $\left(\mathrm{mg} \mathrm{g}^{-1}\right)$}

Supplemental Fig. 3. Relationship between Ca content in roots and N (upper panel), Mg (middle panel), and K (upper panel) for 2017 (red) and 2018 (blue). Lines represent a significant linear relationship. NS, indicates not significant. 
०B9 $\square \mathrm{G} 41 \Delta \mathrm{G} 890 \diamond \mathrm{M} 9$

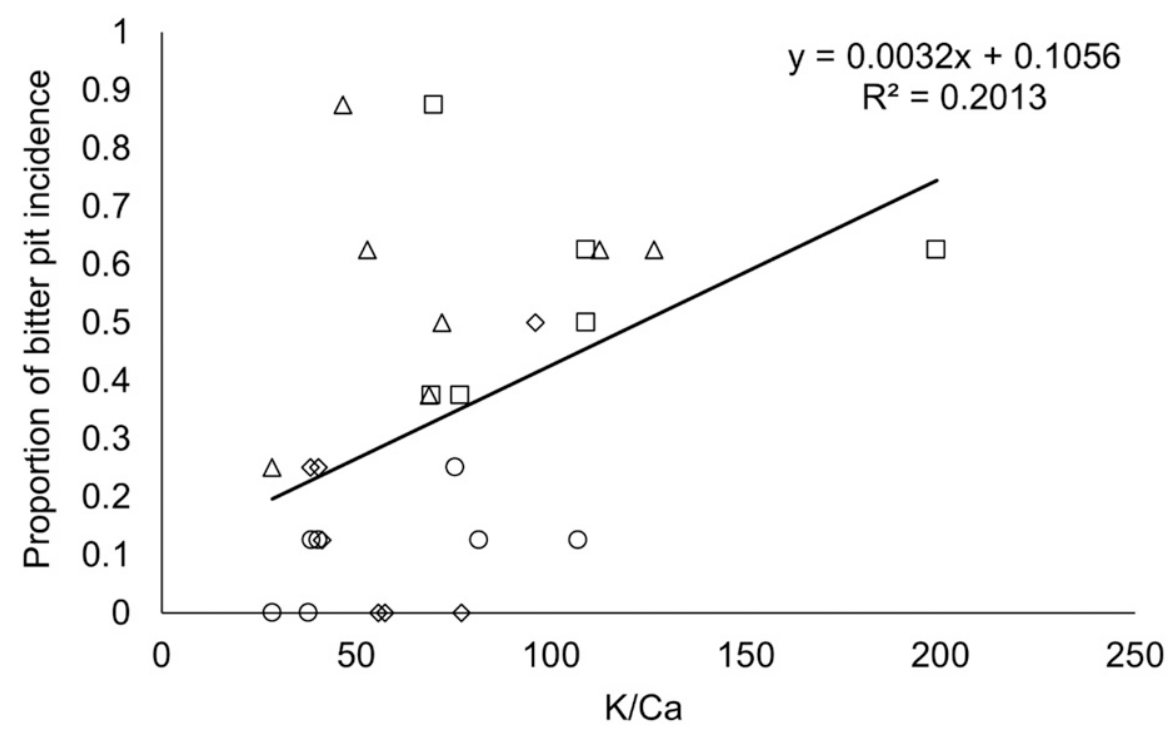

Supplemental Fig. 4. Linear relationship between bitter pit incidence and fruit potassium:calcium ratios for Honeycrisp grafted onto Budagovsky-9 (B9), Geneva-41 (G41), Geneva-890 (G890), or M9-T337 (M9) rootstocks across two growing seasons $(\mathrm{N}=24)$. 